\title{
The Impact of the Development of Urban Sprawl in the Suburbs
}

\author{
Maruttha Puspita Warih', Moh Gamal Rindarjono ${ }^{2}$ and Nurhadi ${ }^{3}$ \\ \{maruttha.geo@student.uns.ac.id ${ }^{1}$,mas6amal@yahoo.com ${ }^{2}$, \& nurhadi@staff.uns.ac.id ${ }^{3}$ \} \\ 1,2,3 Universitas Sebelas Maret, Surakarta, Indonesia
}

\begin{abstract}
Cities development is a natural hapenning experienced by all countries, both developing and developed countries. This study illustrates the development of cities in Indonesia representing urban sprawl growth patterns. The purpose of this study is to identify the impact of the development of Surakarta City towards the suburbs that is towards the Colomadu District. The data collection technique uses multi-temporal image data in 2008-2018 as the basis and uses the method of interviewing, observing, and analyzing documents as a supplement. Data analysis used was descriptive qualitative and spatial analysis to identify land transformation and explore the impact of the development of suburban areas. The results of this study were to discover the impact of urban sprawl in the city of Surakarta towards the outskirts of the city so that it became a suggestion to policy makers to anticipate the impact on the environment.
\end{abstract}

Keywords: environment, land use, rural urban, urban fringe, urban sprawl

\section{INTRODUCTION}

City development has often happened in Indonesia, a change in the city that is increasingly widespread and has an impact on the surrounding environment. Not only is the city's development quite significant in Indonesia, but also the development of urban villages in Indonesia as the impact of urban sprawl is so large and fast. The process of urbanization in Indonesia results in a very diverse face of urban morphology; this is tantamount to other developing countries whose cities are experiencing land and social transformation. A city always experiences development at all times, Java Island is one of the most populated islands living in the city rather than in the village, the number of rural communities has turned urban so that social, economic, cultural and physical structures change.

In Indonesia is the existence of secondary cities that have developed and led to land transformation, one of the secondary cities namely Surakarta City. The development is caused by the increasing flow of urbanization. The term urbanization does not mean the transfer of population from village to city [1]. Urbanization refers to the shifting of the population from rural areas to urban areas. Between 2000 and 2030, the world's urban population is expected to increase by 72 percent, while areas built in cities with a population of 100,000 or more can increase by 175 percent. The United Nations estimates that by 2050 , about 64 percent of developing countries and 86 percent of developed countries will be urbanized [2] and around 
1.1 billion urban new people over the next 13 years [3]. Population growth contributes to changes in land use and form [4].

Cities development has caused the saturation of residential areas and triggered the direction of population spread, especially around the periphery. There is a lot of research in suburban areas, but none focuses on the impact on the living environment and sustainable processes. For example, research on the contribution of economic growth in suburban areas to the national economy conducted by Phelps, the findings in his study showed that suburban areas became the center of national economic growth. Further research by Xu and Zhang [5] showed that some cities in China have significant urbanization and people move from the city center to the suburbs. In contrast to Felton [6], who examined the policy and planning implications for creative industries in the suburbs of Brisbane, Australia. The results of the study show the large number of people living and working in the suburbs. Another study conducted by Rock [7]and Shen [8], they examined the suburban areas of the transportation dimension. Good in the form of the increasing number of private transportation and the effectiveness of the use of trains for suburban residents.

The formulation of the problem in this study is how the impact of urban sprawl towards the suburbs towards the environment. The trigger in the urban fringe problem is basically the spatial transformation process due to the development of very intensive urban areas. In addition, it is to be a suggestion to policy makers to anticipate the negative impacts of urban sprawl development on the environment.

\section{METHOD}

This research was conducted in Colomadu District, Karangayar Regency. Data collection uses 2008-2018 multi temporal image data as the basis and uses interview, observation, and document review methods as a complement. The research subjects were all people living in urban sprawl impact areas in Colomadu District. This study uses a sampling technique in the form of cluster samples or cluster sampling. This technique is taken based on the consideration of the researcher because it sees in terms of time, energy, funds, the narrow extent of the research area, and the size of the risk borne by the researcher. Respondents were representatives from the community, community leaders or important people in the research area and village officials. Data analysis used in this study is qualitative descriptive analysis [9] and spatial analysis. In social science literature and applied professional fields, many naturalistic terms are used to show approaches to qualitative research [10]. Furthermore, spatial analysis is used to identify land transformation over time and explore the impact of developing suburban areas.

\section{RESULT AND DISCUSSION}

The study was conducted in Colomadu District starting with looking for multi-temporal images in order to determine which areas are most affected by urban sprawl, medium and slowest. Then, it was followed by a structured interview conducted to explore information on land changes that occurred. Colomadu District is a sub-district located in Karanganyar Regency. This district is geographically included in the exclave area. Eksklave is an area that is separated and surrounded by other regions and not in one administrative area [11], the exclave can appear for historical, political, or geographical reasons. The area is $15.64 \mathrm{~km}^{2}$ with an average height of 450 meters above sea level [12].

In the past decade, there have been changes in land use. Land changes that occur are for buildings and yards to reach 93 percent to support community activities, mooring at 6.72 
percent, and for ponds / ponds by 0.28 percent. Population growth that occurred in 2008-2018 was 57,084 people. It is clear that there is a significant change in land, where the paddy fields that were originally used for agricultural activities are growing in age and increasing in years, the extent of human activities that are very fast growing will decrease. The existing land does not increase but the number of people is always increasing, this is very often the case, where the construction and establishment of houses for housing and industrial activities that support the fulfillment of the economic needs of the people around the research area. City development in each country is a consequence that must be felt as a result of economic development. Secondary cities are experiencing very fast and predictable developments for more developments in the future. The population of urban dwellers in 2018 is 55 percent and is expected to increase to 68 percent by 2050 [13]. The increasing influence of city life that goes into this village area gradually the life of rural areas will fade. The farther away the village is in the center of the city, the more faded urban appearance can be recognized both in settlements, agricultural land use, and socio-economic or geographically which illustrates the effect of distance on spatial interactions [14]. The suburbs of the city are shaped by cultural, historical, political, social and environmental events. These physical implications have external effects on architectural, urban and regional forms [15]. Physical changes in an area, especially changes in urban land use, make developing suburban areas dynamically [16]. This research shows that this land transformation occurs due to urban sprawl. The migration that took place in Colomadu Subdistrict was one of the reasons for the reduction in paddy fields that were converted into settlements. Hence, migration is a phenomenon that greatly affects people in rural areas [17]. In this study, it is not only the migration process of humans entering the city, but there are effects of the progress of the city so that many residents settle in the suburbs with the intention of obtaining cheaper land and close to workplaces or downtown.

The findings in the field of residents living on the outskirts of the city are due to the large number of livelihoods as private employees located in the center of other cities or districts. Thus, residents who live on the outskirts of the city are not only residents who have a low economic level, but there are those who have a middle to upper economic level. This difference in housing can be seen from the existence of settlements in the form of houses in general and there are houses in the form of complexes/housing. The evolution of settlements in a vertical perspective shows the development of the urban level while the horizontal perspective shows the distance to the urban areas that have been built [18]. The closer the location of the urban area that has been built, the more the city appears and vice versa. The process of urbanization experienced by settlements is the initial level of the countryside leading to urban character. New housing production involves substantially both global and domestic developers and investors [19]. Usually there are four main factors that influence urban land development which are (1) adequate transportation routes capable of encouraging the growth of industrial complexes; (2) proxy with the center of growth; (3) population preference for locations with low population density, moderate settlements and good traffic; and (4) suburbs have sufficient land area [20]. Meanwhile, the results of research found by researchers basically affect the propagation of urban characteristics in the periphery those are (1) many city residents who choose to live in areas with low population density; (2) many residents working in cities choose to live on the edge of the city because land is relatively cheaper; and (3) the land on the outskirts of the city is still wide.

Population density around Surakarta City as an impact of urban sprawl makes the need for land to increase. This happened because of land conversion in the periphery what caused urban growth to affect the extent of agricultural areas and land consumption to be very tight [21]. Even land conversion that occurs in an area causes losses for farmers [22]. Based on map 
overlay, it can be identified that the biggest land transformation is in Malangjiwan Village and Blulukan Village. This increase in population in Colomadu Subdistrict made land use increasingly increasing and reduced agricultural land to settlements. Meanwhile, the regions that experienced the slowest change were in Gajahan Village. In addition to the narrow area, Gajahan Village also does not experience a large population increase in a decade so that land transformation is relatively less.

Research was conducted in several cities to measure the relevance of physical distance in order to know the possible interactions between existing places in a country and to establish the frequency of communication and transportation or travel. In short, it is now known how far the distance needed in relation to the frequency of interactions in the regions before the advent of the internet and technology, and how important that was at this time. However, transportation and communication technologies have not changed the impact of friction between regions, because little attention is paid to spatial patterns. Some urban conditions tend to accelerate mutations to be polycentric with low service levels, high levels of private vehicle ownership, cheap land, and sloping topography. In fact, the polycentric city also promises jobs, wherever it is will attract residents from various parts of the city. However, the travel patterns for each type of city will be different. More and more private vehicles in the surrounding area are one of the factors caused by the large number of workers who live on the edge of the city. Public transportation is not a priority because it makes travel time longer and congestion occurs in the surrounding area. The problem of congestion is usually caused also from the fundamental thing that is the transportation planning factor, because transportation planning factors always influence each other between the pattern of travel and the development of the city. The closer the number of trips to potential destinations, the more expensive the price of the land. The condition of cities in several countries also represents that the change of cities to a sprawl or polycentric form changes the pattern of travel and inefficient mobility of population travel, and shows inefficient urban transportation systems. These conditions indicate that the weak system of controlling urban development in Indonesia while the lack of service in the transportation system will have an impact on inefficient mobility and urban transportation problems.

Essentially urbanization is a process of changing the proportion of the population living in urban area. Urbanization occurring in the world is a gradual change in rural areas that have urban characteristics. In the population order, the impact of urban sprawl on a village has a positive and negative impact[22]. The main elements in the environment are water, air, land and space, so that the development of cities in Indonesia must be considered and observed in order to be able to have a more positive impact, the development of the city if it is not examined properly will make a huge negative impact. The impact of urbanization in developed and developing countries will be different, developing countries will physically see the city grow to be large and wide but inadequate in the technology and quality of life of its population. The negative impact that occurred in Colomadu District was in the form of environmental damage, pollution, congestion, increased use of fuel, and economic monopoly. In addition, the most frequent and easily felt negative impact is the uncontrolled development towards the suburbs will affect mobility and environmental damage.

Mobility problems that occur in the study area lead to inefficient transportation mobility. Spatial policies that are not coordinated with transportation policies will usually lead to the development of cities into polycentric cities. The development of polycentric or sprawl cities tends to be unfavorable for public transportation. For instance, trips made by residents from residence or settlements to workplaces have an irregular pattern, so the construction of public transport infrastructure is less efficient than carrying private vehicles. It is also supported by 
the large number of people in the research area who work as private employees. Hence, there are very many residents who live in suburban areas who use private vehicles. Motorized vehicles in the study area in 2018 reached 5355 vehicles, which at the beginning of 2008 were only 1331 vehicles, for cars in 2008 as many as 555 vehicles and in 2018 as many as 800 vehicles. It proves that in the study area there is a very large increase in vehicles and has the potential to create congestion. Furthermore, the emergence of environmental damage due to the development of Surakarta City has decreased the area of green open space that should exist in every city in Indonesia and the emergence of slums as due to the low environmental awareness in Colomadu Subdistrict, besides that, the increase in vehicle use has resulted in an increase in energy use and carbon dioxide production. Reduced green open space around the city will be a serious problem because it makes the water infiltration site diminish. If water infiltration decreases, then during the rainy season it will be difficult to hold down rainwater and runoff, whereas during the dry season there will be a decrease in the amount of groundwater in the environment. Humans as intelligent creatures and have high abilities compared to other creatures will continue to develop from a simple lifestyle to a modern life. With the development of life, of course, the need for land also increases to be used as residential land and for economic activities. Environmental impacts can also be linked to climate change factors in suburban areas resulting in the vulnerability and impact of climate change [23]. The impact of urban sprawl is caused by climate and the carrying capacity of human activities on the environment, such as the potential for increased flooding and degradation of ecosystems [24].

\section{CONCLUSION}

The conclusion of this study is the development of cities in developing countries including Indonesia which show symptoms of urban sprawl development towards the suburbs. Urbanization that occurs in Colomadu Subdistrict occurs because city residents who choose to live in areas with low population density, residents who work in cities choose to live on the edge of the city because land is relatively cheaper, and land on the outskirts of the city is still large. The process of land transformation makes minimal green open space and reduced paddy fields. It also makes the suburbs more crowded, so that a lot of domestic waste is produced. In addition, the tendency of residents to use private vehicles that cause congestion and increase the use of excess fuel, also makes environmental pollution due to littering.

\section{REFERENCE}

[1] E. Rustiadi, S. Saefulhakim, and D. R. Panuju, Perencanaan dan Pengembangan Wilayah, 2nd ed. Jakarta: Yayasan Pustaka Obor Indonesia, 2011.

[2] United Nations Fund for Population Activities (UNFPA), "World Urbanization Prospects," Jenewa, 2018.

[3] B. Cohen, "Urbanization, City Growth, and the New United Nations Development Agenda," Off. J. World Coal Ind., vol. 3, no. 2, pp. 4-7, 2015.

[4] S. R. P. Sitorus, C. Leonataris, and D. R. Panuju, "Analysis of Land Use Change Pattern and Regional Development in Bekasi City, West Java Provinces," J. Tanah Lingk, vol. 14, no. 1, pp. 21-28, 2012.

[5] Y. Xu and X. Zhang, "The Residential Resettlement in Suburbs of Chinese Cities: A Case Study of Changsha," Cities, vol. 69, no. January, pp. 46-55, 2017.

[6] E. Felton, "Working in The Australian Suburbs: Creative Industries Workers' Adaptation of Traditional Work Spaces," City, Cult. Soc., vol. 4, no. 1, pp. 12-20, 2013. 
[7] S. Rock and B. Caulfield, "The Economic Boom, Bust and Transport Inequity in Suburban Dublin, Ireland," Transp. Econ., vol. 57, pp. 32-43, 2016.

[8] Q. Shen, P. Chen, and H. Pan, "Factors Affecting Car Ownership and Mode Choice in Rail Transit-Supported Suburbs of a Large Chinese City," Transp. Res. Part A, vol. 94, pp. 31-44, 2016.

[9] Creswell, Qualitative Research Introduction. Washington, D.C.: Research \& Learning Research Support Group at the Social Science Research Lab American University, 2009.

[10] L. J. Moleong, Metodologi Penelitian Kualitatif: Edisi Revisi. Bandung: Remaja Rosdakarya, 2014.

[11] S. Wahyuni, Qualitative Research Method Theory and Practice. Jakarta: Salemba Empat, 2012.

[12] Badan Pusat Statistik, "Kecamatan Colomadu dalam Angka 2012," Karanganyar, 2012.

[13] E. Charlesworth, "Cityedge: case studies in contemporary urbanism," p. 244, 2005.

[14] I. P. P. A. Pratama and P. G. Ariastita, "Faktor-Faktor Pengaruh Ukuran Urban Compactness di Kota Denpasar, Bali," J. Tek. ITS, vol. 5, no. 1, 2016.

[15] L. Guran-nica, C. Marin, and N. Todică-ştefan, "Evolution and Impact of Migration Flows in Rural-Urban Fringe Areas. The Case of Romania," vol. 5, no. 2, pp. 249-256, 2011.

[16] T. G. McGee, N. S. Ginsburg, and B. Koppel, "The Emergence Of Desakota Region In Asia: Expanding A Hypothesis," in The Extended Metropolis And Settlement Transsition In Asia, Honolulu: The University Of Hawaii Press, 1991, pp. 3-22.

[17] M. Douglass and B. Wissink, "Enclave urbanism In China: Consequences and interpretations ENCLAVE URBANISM IN CHINA : Faculty of Geosciences," no. June 2015, 2012.

[18] Yeh, H. K. Stephen, and A. A. Laquian, Housing Asia's Millions. Ottawa: International Development Research Centre, 1979.

[19] United Nations, "World Urbanization Prospects," 2018. [Online]. Available: https://www.un.org/development/desa/publications/2018-revision-of-worldurbanizationprospects.html.

[20] P. Van Den Berg, T. Arentze, and H. Timmermans, "A Multilevel Path Analysis of Contact Frequency Between Social Network Members," J. Geogr. Syst., vol. 14, no. 2, pp. 125-141, 2012.

[21] C. Mazzocchi, G. Sali, and S. Corsi, "Land Use Policy Land Use Conversion in Metropolitan Areas and The Permanence of Agriculture: Sensitivity Index of Agricultural Land (SIAL), a Tool for Territorial Analysis," Land use policy, vol. 35, pp. 155-162, 2013.

[22] T. H. T. Nguyen, V. T. Tran, Q. T. Bui, and Q. H. Man, "Socio-economic Effects of Agricultural Land Conversion for Urban Development: Case Study of Hanoi, Vietnam," Land use policy, vol. 54, pp. 583-592, 2016.

[23] R. M. Leichenko and W. D. Solecki, "Urban Climate Climate Change in Suburbs: An Exploration of Key Impacts and Vulnerabilities," Urban Clim., vol. 6, pp. 82-97, 2013.

[24] K. Saddhono, "Cultural and social change of foreign students in Indonesia: The influence of Javanese Culture in Teaching Indonesian to Speakers of Other Languages (TISOL)." IOP Conf. Ser.: Ear. and Envi. Sci.. vol. 126 no. 1 IOP Publishing, 2018. 